JOURNAL OF SECURITY AND SUSTAINABILITY ISSUES

ISSN 2029-7017/ISSN 2029-7025 (online)

2020 Volume 9 January

http://doi.org/10.9770/jssi.2020.9.J(13)

\title{
CORPORATE PERFORMANCE, POLITICAL CONNECTION, FAMILY FIRMS AND CEO TURNOVER IN INDONESIA
}

\author{
Ghassani Awanis ${ }^{1}$, Mohammad Nasih ${ }^{2 *}$ \\ ${ }^{1,2}$ Department of Accountancy, Faculty of Economics and Business, Universitas Airlangga \\ E-mails: ${ }^{2 *}$ Mohnasih@feb.unair.ac.id (Corresponding author)
}

Received 18 March 2019; accepted 15 December 2019; published 30 January 2020

\begin{abstract}
This paper examines relations between company performances, political connection of CEO, political connection of head of commissioner and family firms to CEO turnover. This study uses 1,156 samples of listed firms in Indonesia Stock Exchange from all industries, except financial, during the period of 2011-2017. Ordinary Least Square (OLS) regression is used, and ROA as well as family firms are found to decrease the likelihood of CEO turnover, while Tobin's Q has no significant effect to CEO turnover. It shows that only short-term performance and ownership are taken into account to make decision regarding CEO turnover, while long-term performance is not affecting the decision significantly. In addition, both CEO and head of commissioner's political connection are found to enhance the likelihood of CEO turnover regardless of their differences in roles and tasks. This research findings implies that one of the ways companies adapt is by choosing to appoint CEO with political connection that bring the most benefit for firms at a particular time in a complex political environment such as Indonesia, hence the increased turnover rate. This study helps to explain the implication of performance, upper-management political connection, and family-firm ownership that may influence to the event of CEO turnover in Indonesia.
\end{abstract}

Keywords: Firm performance, political connection, family firm, CEO turnover

Reference to this paper should be made as follows: Awanis, G., Nasih, M, 2020. Corporate performance, political connection, family firms and CEO turnover in Indonesia, Journal of Security and Sustainability Issues, 9(January), 171-185. http://doi.org/10.9770/jssi.2020.9.J(13)

JEL Classifications: M12, M41, M48.

\section{Introduction}

According to law no. 40 year 2007 on limited-liability companies, Indonesia applies a two-tier board system, where company assign board of commissioner to perform the role of supervision and assign board of director to carry out the role of management. This delegation given by the shareholders to managers also means that shareholders have the authority to dismiss members of director through general meeting of shareholder, especially when the current managers cannot fulfill shareholder's expectations and goals of increasing firm's value.

There are two types of turnover, voluntary and involuntary turnover. Unfortunately, there is only little to no public information that is available to distinguish between forced turnovers and voluntary turnover. According to Firth, Fung, \& Rui (2006), even though the stated reason is "change of job," turnover can be either forced or voluntary, not to mention "resignation," a wise choice of CEOs before being dismissed. Supported by Kaplan \& Minton (2011) and Weisbach (1988), they found that both forced turnover and routine turnover has similar patterns in terms of its sensitivity to company's prior performance, emphasizing that even many routine turnovers may be a forced one

Several previous studies investigate the likelihood of CEO for being dismissed when the company are showing signs of poor performances, such as Cooper (2017), Fiordelisi and Ricci (2014), Urban (2019), and Weisbach 
(1988). This result is logical because the main goal of shareholder is to increase shareholder's value, so it is expected that the current manager can continue to do so. Another study conducted by Ghosh \& Wang (2018) also found that there is a positive relationship between poor accounting performance, proxied by accounting losses, and subsequent CEO turnover, because when a company is experiencing a financial loss, investors expects that the company will encounter serious operating and financial problem in the future and is more likely to pay for smaller dividend, which give investor incentives to delegate a newly appointed CEO.

This research also wants to explore and incorporate the influence of political connection into the topic, by examining the influence of politically connected CEO and politically connected head of commissioner. The separation of political connection characteristic between those of CEO's and head of commissioner's is performed due to their differences in roles and tasks according to the dual-board system carried out in Indonesia. Many previous researches on political connection such us from Bliss, Goodwin, Gul \& Wong (2018), Fan \& Chen (2017) and Cheng \& Leung (2016) show that political connections gives benefits for corporation such as it can help firms to obtain key resources, cope with various external uncertainties, and work effectively as a substitute for formal institutions to overcome the gaps in countries that especially have weak institutional environment, thus increasing firm value. In addition, another research by Harymawan (2018) finds that firms that delegated director with military background in Indonesia have lower interest rates than their other counterparty. Backed up with this argument, investor can assume that the political connection of managers is an intangible asset that can benefit the company, thus affecting the decision for CEO dismissal.

However, contradicting hypotheses are found regarding the benefits of political connection for firms. For example, according to Bliss and Gul (2012) who studied about the association between Malaysia political connection and cost of debt, they found that Malaysian politically connected firms incur higher cost of debt than non-political firms because politically connected firms are seen as being more risky than their counterparts. Related to that result, Adams (2005) also examined the relationship between the cost of publicly traded debt and CEO turnover which provides evidence that higher cost of debt of firms are associated with increasing the likelihood of CEO turnover. Thus, it is interesting to study the impact of political connection to CEO turnover.

Countries' political environment may also plays a role in affecting the patterns of management turnover. Indonesia is a country that has a very dynamic political environments as it has tens of political parties and there is rapid changes in the appointed minister. Harymawan, Agustia and Kusuma Agung (2017) and Wati, Primiana, Pirzada, Sudarsono (2019) already found that companies in several types of industries are more likely to be politically connected in Indonesia because of several suggested reasons. The phenomena that companies in certain several industries choose to have political connection may happen because political connection can bring benefits for the firm, outweighting its costs. However, Bonaparte (2017) who has previously study about political repositioning and CEO turnover found that companies in industries that are more politically sensitive exhibit greater political repositioning after a political regime change, which is reflected in increased CEO turnover. This indicates that companies choose to appoint CEOs with political connection that brings the most benefit for the firm at a particular time. Thus, the dynamic and complex political environment in Indonesia may become the reason behind the more rapid CEO turnover in Indonesia.

Board of commissioner is an important governance mechanism to perform the role of supervision of company's business activities and is expected to be able to conduct its duties independently to best represent the interest of shareholders. Several studies has discussed about political connection brought by external members and its effect to good corporate governance, including Kong et al., (2019) who argue that political backgrounds may help independent director to conduct their monitoring role more properly and to improve corporate governance because persons with political connections are more likely to have both employment experience in regulatory agencies and also financial, accounting or law expertises, which support this research results where the likelihood CEO 
turnover increases when company's head of commissioner has some sort of political connection. On the other hand, it is also probable that commissioner with political connections are showing signs of rent-seeking behavior and reduces the extent of supervisions they conducted for the company, supported by the study from Shi, Xu and Zhang (2018).

Weisbach (1988) in his research stated that family dominated companies are generally both tightly held and insider-dominated. This insider-dominated board in family firm may happen because family owners, seeking to exploit the firm's assets for their private benefits, are unlikely to appoint boards that will limit their control of the firm's resources (Setia-Atmaja, 2008). The result of insider-dominated boards means that there may be less need to conduct monitoring in family firms because the goals of principals and agents may become more aligned, which is supported by Westphal (1998) in his research that also suggests that governance mechanisms in family firms are found to be limited

This paper provides new insight as the first research to study about the impact of political connection of head of commissioner to CEO turnover. This study also adds a more complete understanding of the impact between family firm, political connection of company's CEOs and head of commissioners to the association between performance and CEO turnover, considering Indonesia's institutional setting that applies the two-tier board system, separating company's ownership and control, and its complex political environment. The remainder of this paper proceeds as follows: Section 2 reviews the literature and hypotheses, and hypothesis formulation; Section 3 describes sample, variables and research design; Section 4 presents the main results and discusses the findings; Section 5 concludes.

\section{Literature Review}

Mitnick (1973) define that agency relationship exists when one party or "agent" is acting for another party called "principal". According to his paper, such relationship can cause agency problems, including principal's problem and agent's problem. Agent's problem is a choice of acts to resolve a trade-off between self-goals and other goals. Because the agent has more information than the principal regarding the operational of the business, therefore managers must be supervised and controlled in a way that is compliant and obey with the current rules and regulations, which leads to the explanation of principal's problem. Principal's problem is the way to motivate the agents to act in the way that principal wants to achieve principal's goals, resulting in a fee called agency fee or agency cost.

In Indonesia, there are many cases found where politicians and government officials served as company's board of directors and commissioners. According to North (1990) and Olson (1993), politicians or government leaders establish relationships with companies to achieve their agenda that benefits their supporters. However, there is chance that parties with political connection may utilize political resources for their own interest rather than the interest of shareholders (You \& Du, 2011). If the previous statement is hold true, then it is expected that political connection can raise conflict between principal and agent, thus increasing agency costs and affecting the rapidness of CEO turnover as the key determinant of corporate governance.

Meanwhile, family firms, or in this case family owners, are unlikely to appoint boards that will limit their control of the firm's resources (Setia-Atmaja, 2008), supported by the significantly lower proportions of independent directors on the board for family firms. The result of insider-dominated boards means that there may be less need to conduct monitoring in family firms because the goals of principals and agents may become more aligned. This is supported by prior studies of Berle and Means (1932) and Jensen and Meckling (1976) describing that family controlled firms encounter lower owner-manager conflict. Westphal (1998) in his research also suggests that governance mechanisms in family firms are limited, while Mulyani (2016) in her research found that when 
looking at governance mechanism, family firms are often found to have reduced agency costs. All of these reasons are expected to influence the decision for CEO turnover in family firms.

However, family owners in private firms may also possess better ability to monitor and to gather information about firm's current business, and decrease the level of information asymmetry (Tsao, Lin and Chen, 2015). Because principals have more ability to monitor managers and have better understanding about companies' business operations as they see the firm as long-term investment, a more rapid CEO turnover during low performance may happen as an effort to prevent from bankruptcy.

An alternative perspective for political connection comes from the theory of resource-dependence by Pfeiffer and Salancik (1978) suggesting that firms' competitive advantage is based on its possession of key resources that are difficult or pricy for other firms to obtain. Consistent with this view, many prior researches on political connection such us from Bliss, Goodwin, Gul \& Wong (2018), and Cheng \& Leung (2016) explaining that political connections can help firms to obtain key resources, cope with external uncertainties and increase firm value. Another reseach by Harymawan (2018) also find that firms that delegate director with military background have lower interest rates than their other counterparty. In addition, political connection can help firms to minimize expropriation by government official and to seek additional benefits in the form of government subsidies or the avoidance of discretionary charges (Chen et al., 2011) As a result, investors can assume that the political connection that managers have is an intangible asset that can benefit the company, and companies can overcome uncertainty by establishing connections to sources of the uncertainty from governments, therefore affecting the decision regarding CEO turnover. Therefore we develop the following hypotheses:

Hypotheses 1: Firms perfomance is negatively associated with CEO turnover.

Hypotheses 2: Firms with politically connected CEO is negatively associated with CEO turnover.

Hypotheses 3: Firms with politically connected head of commissioner is positively associated with CEO turnover.

Hypotheses 4: Family firms is negatively associated with CEO turnover.

Hypotheses 5: The negative association between ROA and CEO turnover is weaker when the CEO has political connection

Hypothesis 6: The negative association between ROA and CEO turnover is stronger when the head of commissioner has political connection

Hypothesis 7: The negative association between ROA and CEO turnover is weaker in family firms

\section{Research Methodology}

\subsection{Sample and Data Source}

Research data are retrieved from the website of Indonesia Stock Exchange (IDX) and OSIRIS. Samples include all listed firms in IDX between 2011-2017 years. All companies from all industries except those in financial sector are selected in order to get a more comprehensive result in understanding the relationship between all variables under study. Financial companies with SIC number classification between 6000 and 6999 are excluded because they have different business nature and are under different regulation of reporting requirement. Observations with missing data are eliminated. The final number of observations after omitting missing data and SIC 6 companies is 1156 samples. 


\subsection{Variable Measurement}

\subsubsection{Dependent variable: measurement of turnover}

The dependent variable in this study is CEO turnover. This variable is measured by using dummy variable and is assessed by comparing the stated name of CEO in office from company's annual report of current year from the previous year. This variable will be valued as 1 if there are CEO dismissal happens during the year and 0 for otherwise. There are 2 types of CEO Turnover, a routine or voluntary turnover and involuntary turnover. This study does not differentiate between the two categorization because of the lack of available information.

\subsubsection{Independent variable: company performance, measurement of political connection and family firm} This study measures company performance through prior year Returns on Asset (ROA) and Tobin's Q, following previous study from Cheng \& Leung (2016). Those two variables are used to describe the effect of short-term and long-term performance to the dependent variable.

Some prior studies in Indonesia used board connections as the proxy of political connections (Harymawan et al., 2019), political connection of CEO and head of commissioner is valued using dummy variable and is assessed following the Regulation of Bank of Indonesia Number 12/3/PBI/2010 regarding Politically Exposed Person (PEP) at the beginning of the year, including head of state or head of government, deputy head of state or head of government, officials of the ministerial level, senior executives of state enterprises, director of State Owned Enterprises (SOEs), executive and chair of political parties, senior military and/or police officer, senior officials within the supreme court and attorney general's office, officials appointed by presidential decree, family members (spouse, parent, sibling, child, in-law, grandchild) of above categories, and anyone who does not belong to above categories but due to his/her high position/significant influence/celebrity status in the community and/or the combinations of them may put the financial services provider in highly risky position. Political connection is valued as 1 for PEP and 0 otherwise.

The measurement of family firm is conducted using dummy variable to capture the shares owned by family members as a proxy for family ownership that equals 1 when family owns more than $5 \%$ of the firm and 0 otherwise.

\subsubsection{Control Variables}

Following prior studies with related to CEO turnover (Kato \& Long, 2006; Chang \& Wong, 2009; You \& Du, 2011; Cheng \& Leung, 2016; Cao, Pan, Qian \& Tian, 2017; Ghosh and Wang, 2018; Volpin 2002) we use several variables to control turnover, consisting of CEO age, CEO tenure, percentage of independent board, firm size, leverage and sales.

CEO age is the age of CEO at the corresponding year, while CEO tenure is the time period that CEO has served for the company. According to Kato \& Long (2006), "controlling for age and tenure is particularly important because we do not have information on whether CEO turnover is due to normal retirement". Meanwhile, percentage of independent board is the number derived by dividing total number of independent director by total number of board of directors. The value of firm size from calculated by dividing the natural $\log (\ln )$ of company's total asset, while sales is the total Rupiah amount of sales at the corresponding year.

\subsection{Data Analysis Technique}

Heteroscedasticity and winzorizing technique were performed before conducting data analysis test. These technique was conducted to tackle problems when the error variance of a regression model are not constant over different sample observations and extreme data originating from outliers could distort the results of the study (Moy \& Lee, 2000). 
Data analysis in this study is performed using STATA 14.0 software. The data analysis technique used in this study are descriptive analysis, Pearson's correlation test, multicollinearity test and multiple linear regression test. The regression model used for their respective hypotheses in this study are as follows (see table 1 and table 2 as well):

H1, H2, H4 : TURNOVERi,t $=\beta 0+\beta 1$ LAGROAi,t-1 $+\beta 2$ LAGTOBINSi,t $1+\beta 3$ PCON_CEOi,t + $\beta 4$ FAMILYi,t $+\beta$ CEEOAGEi,$t+\beta 6$ TENUREi,$t+\beta$ INDPBOARDi,t $+\beta 8$ FIRMSIZEi, $t+\beta$ 9LEVERAGEi, $t+$ $\beta 10$ SALESi,t $+\varepsilon i, \mathrm{t}$

H1, H3, H4 : TURNOVERi, $t=\beta 0+\beta 1$ LAGROAi,t-1 + $\beta 2$ LAGTOBINSi,t-1 $+\beta 3$ PCON_HCi,t $+\beta 4 F A M I L Y i, t$

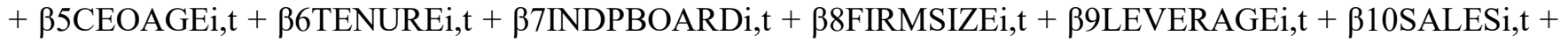
$\varepsilon \mathrm{i}, \mathrm{t}$

H5: TURNOVERi,t $=\beta 0+\beta 1$ LAGROA $*$ PCON_CEOi,t-1 + $\beta 2$ LAGROAi,t-1+ $\beta 3$ PCON_CEOi,t+ $\beta 4$ FAMILYi,t

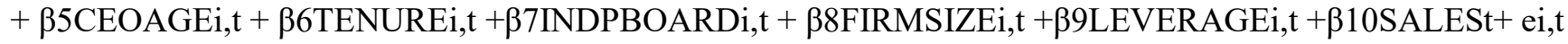

H6: TURNOVERi,t $=\beta 0+\beta 1$ LAGROA $*$ PCON_HCi,t-1 $+\beta 2$ LAGROAi,t- $1+\beta 3$ PCON_HCi,t+ $\beta 4$ FAMILYi,t +

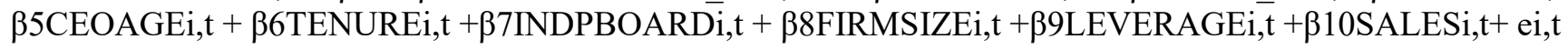

H7: TURNOVERi,t $=\beta 0+\beta 1$ LAGROA*FAMILYi,t-1 $+\beta 2$ LAGROAi,t- $1+\beta 3$ FAMILYi, $+\beta 4$ CEOAGEi,t +

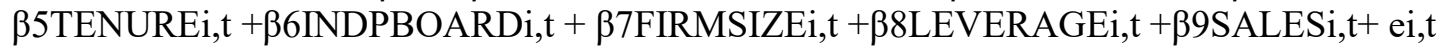

Table 1. Sample Selection

\begin{tabular}{|l|l|}
\hline Description & Total \\
\hline Total number of listed public companies in IDX and OSIRIS during 2011-2017. & 4,017 \\
\hline Less companies with SIC between 6000 and 6999 & $(938)$ \\
\hline Less companies with missing data or incomplete data & $(1,923)$ \\
\hline Number of companies used as observation samples & 1156 \\
\hline
\end{tabular}


Table 2. Variable Definiton

\begin{tabular}{|l|l|l|}
\hline Variable & Definition & Data Source \\
\hline Dependent & $\begin{array}{l}\text { A dummy variable on whether there are any changes of CEO in office } \\
\text { compared to last year }\end{array}$ & Annual Report \\
\hline CEO Turnover & & \\
\hline Independent & & OSIRIS \\
\hline Firm Performance: & Ratio of net income to total asset of prior year & OSIRIS \\
\hline LAGROA & Ratio of debt and equity market value to total asset of prior year & Annual Report \\
\hline PCON_CEO & $\begin{array}{l}1 \text { if CEO is PEP according to Bank Indonesia Regulation Number } \\
12 / 3 / \text { PBI/2010 article } 11,0 \text { otherwise }\end{array}$ & \\
\hline PCON_HC & 1 if Commissioner is PEP according to Bank Indonesia Regulation & Annual Report \\
Number $12 / 3 /$ PBI/2010 article 11,0 otherwise & \\
\hline FAMILY & 1 if family firm, 0 otherwise & Annual Report \\
\hline Control & & Annual Report \\
\hline CEOAGE & Age of CEO at the corresponding year & Annual Report \\
\hline TENURE & Time period that CEO has served for the company & OSIRIS \\
\hline INDBOARD & $\begin{array}{l}\text { Ratio of number of independent board to total number of board of } \\
\text { directors }\end{array}$ & OSIRIS \\
\hline FIRMSIZE & Natural log. of asset & OSIRIS \\
\hline LEVERAGE & Ratio of total debt to total asset & OSIRIS \\
\hline SALES & Amount of sales & OSIRIS \\
\hline INDUSTRY & Fixed industry effects & Fixed year effects \\
\hline YEAR & & \\
\hline
\end{tabular}

\section{Result and Discussion}

\subsection{Descriptive Statistics}

Descriptive statistic is presented in table 3 below, all data presented has been winsorized. Mean for CEO turnover is 0.000. Among 1156 observations, 167 samples are having turnover during 2011-2017. Mean of five independent, namely lag of ROA, lag of Tobin's Q, CEO political connection, head of commissioner political connection and family firms are 5,481, 1.157, 0.105, 0.193 and 0.329 respectively, while the median is 4.510 , $0.589,0.000,0.000$ and 0.000 respectively. From this data it can be concluded that there are more non-politically connected firms that politically connected ones (see table 3 ).

Table 3. Descriptive Statistics

\begin{tabular}{|c|c|c|c|c|}
\hline & Mean & Median & Minimum & Maximum \\
\hline TURNOVER & 0.144 & 0.000 & 0.000 & 1.000 \\
\hline LAGROA & 5.481 & 4.510 & -30.920 & 47.920 \\
\hline LAGTOBINS & 1.157 & 0.589 & 0.014 & 10.326 \\
\hline PCON_CEO & 0.105 & 0.000 & 0.000 & 1.000 \\
\hline PCON_HC & 0.193 & 0.000 & 0.000 & 1.000 \\
\hline FAMILY & 0.329 & 0.000 & 0.000 & 1.000 \\
\hline
\end{tabular}


JOURNAL OF SECURITY AND SUSTAINABILITY ISSUES

ISSN 2029-7017/ISSN 2029-7025 (online)

2020 Volume 9 Number January

http://doi.org/10.9770/jssi.2020.9.J(13)

\begin{tabular}{|c|c|c|c|c|}
\hline CEOAGE & 52.760 & 52.000 & 33.000 & 77.000 \\
\hline TENURE & 7.631 & 5.000 & 0.000 & 40.000 \\
\hline INDBOARD & 0.120 & 0.111 & 0.000 & 0.500 \\
\hline FIRMSIZE & 21.753 & 21.905 & 17.242 & 25.575 \\
\hline LEVERAGE & 0.536 & 0.506 & 0.077 & 2.554 \\
\hline SALES & $6.898 \mathrm{e}+09$ & $2.057 \mathrm{e}+09$ & 10202426.000 & $8.297 \mathrm{e}+10$ \\
\hline
\end{tabular}

Notes:

This table shows the descriptive statistics for all the variables used in this study. The sample used in this study amounted to 1156 companies listed on the IDX in 2010-2017.

This study also employs Pearson correlation test shown in table 4. It shows the correlation between variables under this study. The Pearson Correlation Test implies that 3 from the 5 independent variables affect our dependent variable significantly. Company performances, which are proxied by both lag of ROA and lag of Tobin's Q, do not give significant results. Lag of ROA shows the coefficient of $-0.045(\mathrm{t}=0.127)$ and lag of Tobin's Q shows the coefficient of $-0.017(\mathrm{t}=0.575)$.

Meanwhile, CEO political connection increase the rate of CEO turnover with the coefficient of $0.060(\mathrm{t}=0.040)$, at $5 \%$ significance level. This result suggests that firms which hire politically connected CEO has a higher rate of turnover. The relation between head of commissioner political connection and CEO turnover deliver the coefficient of $0.073(\mathrm{t}=0.012)$, at $5 \%$ significance level. This result suggests that firms which hire politically connected head of commissioner has a higher rate of turnover. Last, family firm in relation with CEO turnover shows the result with a coefficient of $-1.104(\mathrm{t}=0.000)$, at $1 \%$ significance level. This result illustrates that family firms are having an overall lower rate of CEO turnover.

\subsection{Regression Analysis}

Table 5 represent the regression result for our hypotheses which analyze the relationship between our independent variable and dependent variable using OLS. Column [1] shows the relationship between lag of ROA, lag of Tobin's Q, CEO political connection, family firm and CEO turnover, and column [2] shows the relationship between lag of ROA, lag of Tobin's Q, head of commissioner political connection, family firm and CEO turnover. From the table 5 we can see that the coefficient of ROA to turnover is negative (the coefficient are -0.002 at first column and -0.002 at second column) and significant at 5\% percent level (t-statistic $=-2.03$ and -2.11 respectively), meaning higher company's previous year ROA decrease the likelihood for CEO turnover.

Meanwhile, Tobin's Q coefficient value is 0.005 at first column and 0.005 at second column, with t-value of 0.74 and 0.69 respectively, meaning that company's previous year Tobin's Q is not significantly influencing the decision for CEO turnover. PCON_CEO also has coefficient value of 0.084 at first column and is significant at $5 \%$ significant level, with t-value of 2.33 , meaning that political connection of CEO enhances the likelihood of CEO turnover (see Table 4). 
Table 4. Pearson Correlation

\begin{tabular}{|c|c|c|c|c|c|c|c|c|c|c|c|c|}
\hline & [1] & [2] & [3] & [4] & [5] & [6] & [7] & [8] & [9] & [10] & [11] & {$[12]$} \\
\hline \begin{tabular}{|l|}
$1]$ \\
TURNOVER
\end{tabular} & 1.000 & & & & & & & & & & & \\
\hline \multicolumn{13}{|l|}{ A } \\
\hline \multirow[t]{2}{*}{ [2] LAGROA } & -0.045 & 1.000 & & & & & & & & & & \\
\hline & $(0.127)$ & & & & & & & & & & & \\
\hline \multirow[t]{2}{*}{\begin{tabular}{|l|}
{$[3]$} \\
LAGTOBINS \\
\end{tabular}} & 0.017 & $0.448^{* * * *}$ & 1.000 & & & & & & & & & \\
\hline & $(0.575)$ & $(0.000)$ & & & & & & & & & & \\
\hline \multirow[t]{2}{*}{\begin{tabular}{|l}
{$[4]$} \\
PCON_CEO
\end{tabular}} & $0.060^{* *}$ & 0.032 & -0.038 & 1.000 & & & & & & & & \\
\hline & $(0.040)$ & $(0.275)$ & $(0.198)$ & & & & & & & & & \\
\hline \multirow[t]{2}{*}{ [5] PCON_HC } & $0.073^{* *}$ & $0.052^{*}$ & -0.013 & $0.470^{* * *}$ & 1.000 & & & & & & & \\
\hline & $(0.012)$ & $(0.078)$ & $(0.669)$ & $(0.000)$ & & & & & & & & \\
\hline \multirow[t]{2}{*}{ [6] FAMILY } & $-0.104^{* * * *}$ & -0.005 & -0.029 & $-0.065^{* *}$ & $-0.151^{* * *}$ & 1.000 & & & & & & \\
\hline & $(0.000)$ & $(0.878)$ & $(0.325)$ & $(0.028)$ & $(0.000)$ & & & & & & & \\
\hline \multirow[t]{2}{*}{ [7] CEOAGE } & $-0.100^{* * *}$ & -0.011 & $-0.077^{* * *}$ & $0.074^{* * *}$ & 0.033 & $0.071^{* *}$ & 1.000 & & & & & \\
\hline & $(0.001)$ & $(0.713)$ & $(0.009)$ & $(0.012)$ & $(0.269)$ & $(0.016)$ & & & & & & \\
\hline \multirow[t]{2}{*}{ [8] TENURE } & $-0.166^{* * * *}$ & -0.019 & $-0.122^{* * * *}$ & -0.021 & $-0.067^{* *}$ & $0.203^{* * * *}$ & $0.345^{* * * *}$ & 1.000 & & & & \\
\hline & $(0.000)$ & $(0.515)$ & $(0.000)$ & $(0.486)$ & $(0.022)$ & $(0.000)$ & $(0.000)$ & & & & & \\
\hline \multirow{2}{*}{$\begin{array}{l}{[9]} \\
\text { INDBOARD } \\
\end{array}$} & -0.001 & $-0.072^{* *}$ & 0.034 & $-0.127^{* * *}$ & 0.009 & -0.025 & $-0.049^{*}$ & $-0.060^{* * *}$ & 1.000 & & & \\
\hline & $(0.982)$ & $(0.014)$ & $(0.247)$ & $(0.000)$ & $(0.763)$ & $(0.388)$ & $(0.098)$ & $(0.043)$ & & & & \\
\hline \multirow[t]{2}{*}{\begin{tabular}{|l|}
{$[10]$} \\
FIRMSIZE \\
\end{tabular}} & -0.011 & $0.180^{* * * *}$ & 0.047 & $0.267^{* * * *}$ & $0.177^{* * *}$ & $-0.078^{* * *}$ & 0.024 & $-0.112^{* * * *}$ & -0.043 & 1.000 & & \\
\hline & $(0.696)$ & $(0.000)$ & $(0.108)$ & $(0.000)$ & $(0.000)$ & $(0.008)$ & $(0.412)$ & $(0.000)$ & $(0.146)$ & & & \\
\hline \multirow[t]{2}{*}{$\begin{array}{l}{[11]} \\
\text { LEVERAGE }\end{array}$} & $-0.053^{*}$ & $-0.367^{* * *}$ & $-0.191^{* * * *}$ & -0.013 & -0.024 & $-0.075^{* *}$ & $-0.066^{* *}$ & 0.001 & 0.011 & $0.051^{*}$ & 1.000 & \\
\hline & $(0.071)$ & $(0.000)$ & $(0.000)$ & $(0.655)$ & $(0.416)$ & $(0.011)$ & $(0.024)$ & $(0.961)$ & $(0.714)$ & $(0.081)$ & & \\
\hline \multirow{2}{*}{\begin{tabular}{|l|l|} 
[12] SALES \\
\end{tabular}} & -0.015 & $0.230^{* * * *}$ & $0.111^{* * * *}$ & $0.237^{* * *}$ & $0.118^{* * * *}$ & $-0.054^{*}$ & -0.017 & $-0.071^{* *}$ & $-0.168^{* * *}$ & $0.618^{* * *}$ & -0.000 & 1.000 \\
\hline & $(0.613)$ & $(0.000)$ & $(0.000)$ & $(0.000)$ & $(0.000)$ & $(0.068)$ & \begin{tabular}{|l|l|}
$(0.558)$ \\
\end{tabular} & $(0.016)$ & $(0.000)$ & $(0.000)$ & $(0.988)$ & \\
\hline
\end{tabular}

\section{Notes:}

This table shows the Pearson correlation results in 1156 samples of firms listed in IDX between 2010-2017

$* * *$ Correlation is significant at the $1 \%$ level (2-tailed); **Correlation is significant at the $5 \%$ level (2-tailed); *Correlation is significant at the $10 \%$ level (2-tailed)

PCON_HC has a coefficient value of 0.055 at second column and is significant at $5 \%$ significant level, with tvalue of 2.05, meaning that political connection of the head of commissioner increase the probability of CEO turnover. Furthermore, FAMILY has a coefficient value of -0.059 at first column and -0.055 at second column, significant at $1 \%$ and 5\% significant level, with t-value of -2.63 and -2.46 respectively, meaning that family firms has a significant and negative relationship with CEO turnover (see table 5). 
JOURNAL OF SECURITY AND SUSTAINABILITY ISSUES

ISSN 2029-7017/ISSN 2029-7025 (online)

2020 Volume 9 Number January

http://doi.org/10.9770/jssi.2020.9.J(13)

Table 5. Regression Result

\begin{tabular}{|c|c|c|c|}
\hline & $\begin{array}{l}\text { Prediction } \\
\text { Sign }\end{array}$ & $\begin{array}{l}\text { [1] } \\
\text { TURNOVER }\end{array}$ & $\begin{array}{l}{[2]} \\
\text { TURNOVER }\end{array}$ \\
\hline LAGROA & - & $\begin{array}{l}-0.002^{* *} \\
(-2.03)\end{array}$ & $\begin{array}{l}-0.002^{* *} \\
(-2.11)\end{array}$ \\
\hline LAGTOBINS & - & $\begin{array}{l}0.005 \\
(0.74)\end{array}$ & $\begin{array}{l}0.005 \\
(0.69)\end{array}$ \\
\hline PCON_CEO & - & $\begin{array}{l}0.084^{* *} \\
(2.33)\end{array}$ & \\
\hline PCON_HC & + & & $\begin{array}{l}0.055^{* *} \\
(2.05)\end{array}$ \\
\hline FAMILY & - & $\begin{array}{l}-0.059^{* * * *} \\
(-2.63)\end{array}$ & $\begin{array}{l}-0.055^{* *} \\
(-2.46)\end{array}$ \\
\hline CEOAGE & + & $\begin{array}{l}-0.003^{* *} \\
(-2.19)\end{array}$ & $\begin{array}{l}-0.003^{* *} \\
(-2.10)\end{array}$ \\
\hline TENURE & - & $\begin{array}{l}-0.006^{* * *} \\
(-4.38)\end{array}$ & $\begin{array}{l}-0.006^{* * *} \\
(-4.30)\end{array}$ \\
\hline INDBOARD & + & $\begin{array}{l}-0.069 \\
(-0.78)\end{array}$ & $\begin{array}{l}-0.091 \\
(-1.03)\end{array}$ \\
\hline FIRMSIZE & - & $\begin{array}{l}-0.006 \\
(-0.74)\end{array}$ & $\begin{array}{l}-0.005 \\
(-0.61)\end{array}$ \\
\hline LEVERAGE & + & $\begin{array}{l}-0.090^{* * * *} \\
(-2.72)\end{array}$ & $\begin{array}{l}-0.091^{* * *} \\
(-2.74)\end{array}$ \\
\hline SALES & - & $\begin{array}{l}-0.000 \\
(-0.53)\end{array}$ & $\begin{array}{l}-0.000 \\
(-0.37)\end{array}$ \\
\hline _cons & $?$ & $\begin{array}{l}0.573^{* * *} \\
(3.09)\end{array}$ & $\begin{array}{l}0.548^{* * * *} \\
(2.97)\end{array}$ \\
\hline Industry Dummies & & Yes & Yes \\
\hline Year Dummies & & Yes & Yes \\
\hline$r^{2}$ & & 0.066 & 0.065 \\
\hline Adjusted $r^{2}$ & & 0.047 & 0.046 \\
\hline F-value & & 3.45 & 3.40 \\
\hline$N$ & & 1156 & 1156 \\
\hline
\end{tabular}

Notes:

This table shows the results of ordinary least square regressions between company performances, CEO and head of commissioner political connection, family firm and CEO turnover with sample of 1165 firms listed on the IDX 2010-2017 with significance at 10\%, 5\% and 1\%

Additionally, authors conduct robustness test to support our main finding, presented at table 6 at the end of this paper. Same like the previous table, Column [1] shows the relationship between lag of ROA, lag of Tobin's Q, CEO political connection, family firm and CEO turnover, and column [2] shows the relationship between lag of ROA, lag of Tobin's Q, head of commissioner political connection, family firm and CEO turnover. From table 6 we can see that the coefficient of LAGROA to TURNOVER is negative (the coefficient are -0.002 at first column and -0.002 at second column) and significant at $10 \%$ and $5 \%$ percent level respectively (t-statistic $=-1.90$ and 1.97 respectively), meaning higher company's previous year ROA decrease the likelihood for CEO turnover. Meanwhile, LAGTOBINS's coefficient value is 0.005 at first column and 0.005 at second column, with t-value of 0.69 and 0.65 respectively, meaning that company's previous year Tobin's $Q$ is not significantly influencing the decision for CEO turnover. PCON_CEO also has coefficient value of 0.084 at first column and is significant at $5 \%$ significant level, with t-value of 2.09, meaning that political connection of CEO enhances the likelihood of CEO turnover. Meanwhile, PCON_HC also has a coefficient value of 0.055 at second column and is significant at $10 \%$ significant level, with t-value of 1.87 , meaning that political connection of the head of commissioner increase the probability of CEO turnover. Furthermore, FAMILY has a coefficient value of -0.059 at first column 
JOURNAL OF SECURITY AND SUSTAINABILITY ISSUES

ISSN 2029-7017/ISSN 2029-7025 (online)

2020 Volume 9 Number January

http://doi.org/10.9770/jssi.2020.9.J(13)

and -0.055 at second column, both significant at $1 \%$ significant level, with t-value of -2.80 and -2.64 respectively, meaning that family firms has a significant and negative relationship with CEO turnover.

The result shows that lag of ROA has a significant negative effect as stated in the hypothesis, while lag of Tobin's $\mathrm{Q}$ has no significant effect to CEO turnover. This result implies that company's performance in stock market is not being considered to make decision regarding CEO turnover in Indonesia.

Tobin Q is related to the future prospects of the firm viewed by the stock market. Tobin's Q incorporates market value of asset in its nominator and replacement cost of asset as its denominator. According to theory of Tobin's Q, firms with various profitable investment opportunities has higher market value because these profit opportunities mean higher future income for shareholders and higher long-term operating performance (Hall, Lotti, \& Mairesse, 2013 and Bhana, 2013). Thus, companies with higher Tobin's Q are those with higher growth opportunities.

In addition, according to Hayes, A.F. (2017), the interaction between independent variable and moderating variable must be significant in order to claim moderation interaction, because the moderator explains when a dependent variable and independent variables are related. According to table 7, there is no significant evidence that LAGROAxPCONCEO affects CEO turnover. This result indicates that CEO political connection does not moderate the relationship between ROA and CEO turnover because of the insignificant $t$-value result, meaning that the association between LAGROA on TURNOVER is not influenced by PCON_CEO. This may happen because the individual effect of LAGROA and PCON_CEO counteract each other, resulting in a nonsignificant result.

Commissioner is an important governance mechanism to perform the role of supervision of company's business activities in order to help protect the interest of investor. Agency theory mentions that conflicts of interest can arise because the objectives of the commissioner and the CEO are not automatically the same. According to Kong, Xiang, Zhang \& Lu (2019), locally connected independent directors are more likely to have both employment experience in regulatory agencies and also financial, accounting or law expertise. This unique experiences and expertises brought by politically connected persons, or in this case, commissioners, may help commissioners with political connection to perform better monitoring role effectively and to improve corporate governance. According to the results shown at table 7, it is clear that the LAGROAxPCONHC has a coefficient value of -0.004 for both OLS and Robust analysis and is significant at 5\% significant level in the third and fourth column, with t-value of -2.04 and -1.78 respectively. It can concluded that if a firm employs politically connected head of commissioner in the midst of high firm performance as proxied by lag of ROA, then likelihood for CEO turnover will lower by -0.004 compared to in the condition without moderating variable which is -0.002 . Politically connected head of commissioners proves to strengthen the effect of corporate performance to CEO turnover. As a result, hypothesis 7 is accepted.

In relation with family companies, Weisbach (1988) in his research stated that family dominated companies are generally both tightly held and insider-dominated. This insider-dominated board in family firm may happen because family owners, seeking to exploit the firm's assets for their private benefits, are unlikely to appoint boards that will limit their control of the firm's resources (Setia-Atmaja, 2008). Setia-Atmaja (2008) in their paper also found that family firms have significantly lower proportions of independent directors on the board. The result of insider-dominated boards means that there may be less need to conduct monitoring in family firms because the goals of principals and agents may become more aligned. However, it is shown that there is no significant evidence that LAGROAxFAMILY affects CEO turnover. This result indicates that family firms does not moderate the relationship between performance proxied by ROA and CEO turnover because of the insignificant tvalue result, meaning that the impact of LAGROA on TURNOVER is not influenced by FAMILY (see table 6 and table 7). 
Table 6. Robustness test for company's performance, CEO and head of commissioner's political connection, family firms to CEO turnover

\begin{tabular}{|c|c|c|c|}
\hline & $\begin{array}{l}\text { Prediction } \\
\text { Sign }\end{array}$ & $\begin{array}{l}\text { (1) } \\
\text { TURNOVER } \\
\end{array}$ & $\begin{array}{l}\text { (2) } \\
\text { TURNOVER }\end{array}$ \\
\hline LAGROA & - & $\begin{array}{l}-0.002^{*} \\
(-1.90) \\
\end{array}$ & $\begin{array}{l}-0.002^{* * *} \\
(-1.97) \\
\end{array}$ \\
\hline LAGTOBINS & - & $\begin{array}{l}0.005 \\
(0.69) \\
\end{array}$ & $\begin{array}{l}0.005 \\
(0.65) \\
\end{array}$ \\
\hline PCON_CEO & - & $\begin{array}{l}0.084^{* *} \\
(2.09)\end{array}$ & \\
\hline PCON_HC & + & & $\begin{array}{l}0.055^{*} \\
(1.87)\end{array}$ \\
\hline FAMILY & - & $\begin{array}{l}-0.059^{* * *} \\
(-2.80) \\
\end{array}$ & $\begin{array}{l}-0.055^{* * * *} \\
(-2.64) \\
\end{array}$ \\
\hline CEOAGE & + & $\begin{array}{l}-0.003^{* *} \\
(-2.11)\end{array}$ & $\begin{array}{l}-0.003^{* *} \\
(-2.03)\end{array}$ \\
\hline TENURE & - & $\begin{array}{l}-0.006^{* * *} \\
(-3.98)\end{array}$ & $\begin{array}{l}-0.006^{* * * *} \\
(-3.88)\end{array}$ \\
\hline INDBOARD & + & $\begin{array}{l}-0.069 \\
(-0.78) \\
\end{array}$ & $\begin{array}{l}-0.091 \\
(-1.02) \\
\end{array}$ \\
\hline FIRMSIZE & - & $\begin{array}{l}-0.006 \\
(-0.68)\end{array}$ & $\begin{array}{l}-0.005 \\
(-0.56)\end{array}$ \\
\hline LEVERAGE & + & $\begin{array}{l}-0.090^{* * * *} \\
(-3.87)\end{array}$ & $\begin{array}{l}-0.091^{* * *} \\
(-3.90)\end{array}$ \\
\hline SALES & - & $\begin{array}{l}-0.000 \\
(-0.57)\end{array}$ & $\begin{array}{l}-0.000 \\
(-0.40)\end{array}$ \\
\hline _cons & $?$ & $\begin{array}{l}0.573^{\text {*** }} \\
(2.75) \\
\end{array}$ & $\begin{array}{l}0.548^{* * *} \\
(2.62)\end{array}$ \\
\hline Industry Dummies & & Yes & Yes \\
\hline Year Dummies & & Yes & Yes \\
\hline $\mathbf{r}^{2}$ & & 0.066 & 0.065 \\
\hline Adjusted $\mathbf{r}^{2}$ & & 0.047 & 0.046 \\
\hline F-value & & . & . \\
\hline$N$ & & 1156 & 1156 \\
\hline
\end{tabular}

Notes:

This table shows results of robust ordinary least square regressions between performances, CEO and head of commissioner political connection, family firm and CEO turnover with sample of 1165 firms listed on the IDX 2010-2017 with significance at $10 \%, 5 \%$ and $1 \%$

Table 7. OLS and Robustness regression test for company's performance and CEO turnover with CEO's political connection, head of commissioner's political connection and family firms as moderating variables

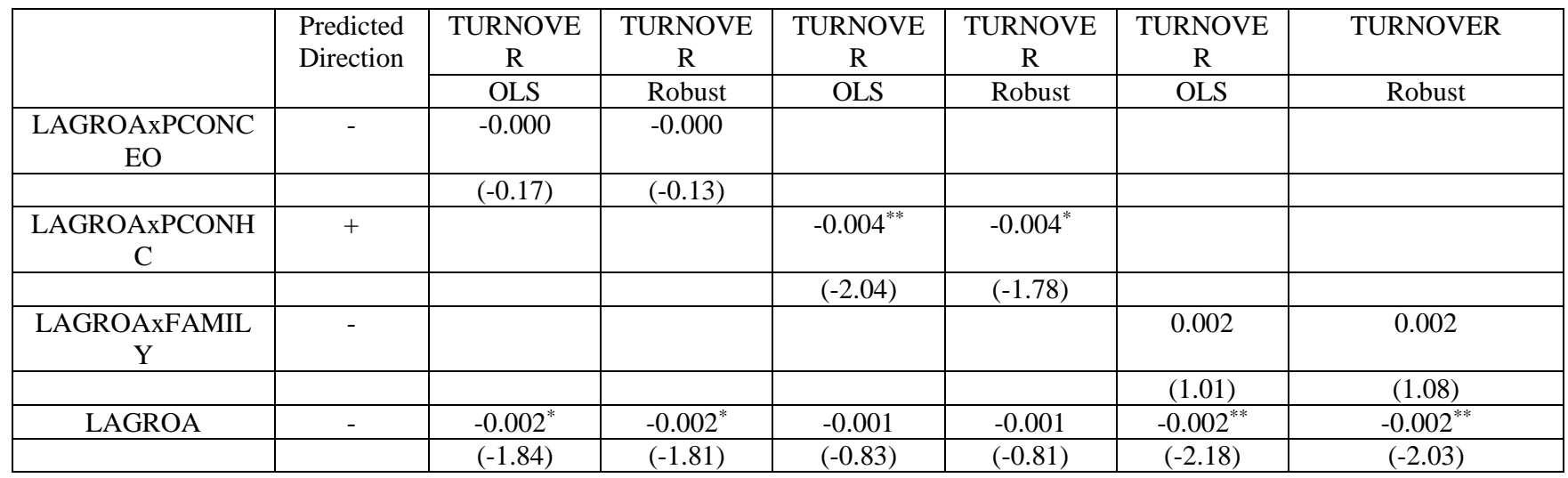


JOURNAL OF SECURITY AND SUSTAINABILITY ISSUES

ISSN 2029-7017/ISSN 2029-7025 (online)

2020 Volume 9 Number January

http://doi.org/10.9770/jssi.2020.9.J(13)

\begin{tabular}{|c|c|c|c|c|c|c|c|}
\hline PCON_CEO & - & 0.066 & 0.066 & $0.068^{*}$ & 0.068 & 0.063 & 0.063 \\
\hline & & $(1.54)$ & $(1.39)$ & $(1.70)$ & $(1.58)$ & $(1.60)$ & $(1.46)$ \\
\hline PCON_HC & + & 0.035 & 0.035 & $0.060^{*}$ & $0.060^{*}$ & 0.037 & 0.037 \\
\hline & & $(1.19)$ & $(1.10)$ & $(1.87)$ & $(1.65)$ & $(1.25)$ & $(1.16)$ \\
\hline FAMILY & - & $-0.056^{* *}$ & $-0.056^{* * *}$ & $-0.059^{* * *}$ & $-0.059^{* * *}$ & $-0.068^{* * *}$ & $-0.068^{* * *}$ \\
\hline & & $(-2.49)$ & $(-2.70)$ & $(-2.63)$ & $(-2.82)$ & $(-2.67)$ & $(-2.89)$ \\
\hline CEOAGE & + & $-0.003^{* *}$ & $-0.003^{* *}$ & $-0.003^{* *}$ & $-0.003^{* *}$ & $-0.003^{* *}$ & $-0.003^{* * *}$ \\
\hline & & $(-2.22)$ & $(-2.14)$ & $(-2.27)$ & $(-2.18)$ & $(-2.19)$ & $(-2.11)$ \\
\hline TENURE & - & $-0.006^{* * *}$ & $-0.006^{* * *}$ & $-0.006^{* * *}$ & $-0.006^{* * *}$ & $-0.006^{* * *}$ & $-0.006^{* * *}$ \\
\hline & & $(-4.46)$ & $(-4.05)$ & $(-4.39)$ & $(-3.94)$ & $(-4.37)$ & $(-3.91)$ \\
\hline INDBOARD & + & -0.075 & -0.075 & -0.068 & -0.068 & -0.079 & -0.079 \\
\hline FIRMSIZE & & $(-0.85)$ & $(-0.86)$ & $(-0.78)$ & $(-0.78)$ & $(-0.90)$ & $(-0.90)$ \\
\hline & - & -0.007 & -0.007 & -0.008 & -0.008 & -0.008 & -0.008 \\
\hline LEVERAGE & + & $-0.090^{* * *}$ & $-0.090^{* * *}$ & $-0.087^{* * *}$ & $-0.087^{* * *}$ & $-0.088^{* * *}$ & $(-0.86)$ \\
\hline & & $(-2.71)$ & $(-3.86)$ & $(-2.65)$ & $(-3.76)$ & $(-2.67)$ & $-0.088^{* * *}$ \\
\hline SALES & - & -0.000 & -0.000 & -0.000 & -0.000 & -0.000 & $(-3.80)$ \\
\hline & & $(-0.41)$ & $(-0.44)$ & $(-0.37)$ & $(-0.40)$ & $(-0.37)$ & -0.000 \\
\hline & & $0.595^{* * *}$ & $0.595^{* * *}$ & $0.608^{* * *}$ & $0.608^{* * *}$ & $0.613^{* * *}$ & $(-0.39)$ \\
\hline & & $(3.22)$ & $(2.87)$ & $(3.30)$ & $(2.95)$ & $(3.31)$ & $\left(2.613^{* * *}\right.$ \\
\hline
\end{tabular}

\section{Conclusions}

Our study investigates whether company performance CEO and head of commissioner political connection and family firm enhance the probability of CEO turnover in Indonesia. Using total sample of 1156 firm-years listed firms in Indonesia, we document that there is a positive and significant relationship between CEO political connection and commissioner political connection, which may happens because of the complex political environment in Indonesia. We also find the association between ROA and family firm which lowers the probability of CEO turnover, but Tobin's Q is not significantly associated with CEO turnover. Our study suggests that only short-term company's performance is being considered by shareholders to make decision regarding CEO turnover. In addition, family firms has been proven to have a lower rate of CEO turnover in Indonesia.

CEO political connection doesn't moderate the relationship between ROA and CEO turnover. Head of commissioner political connection strengthen the relationship between ROA and CEO turnover. When the relationship between ROA and CEO turnover is interacted with political connection of the head of commissioner, the relationship between ROA and CEO turnover becomes stronger. Family firm doesn't moderate the relationship between ROA and CEO turnover

Authors acknowledge some limitations while conducting this study. For example When measuring CEO turnover variable, this study does not differentiate between voluntary and involuntary turnover because of the lack of available information and the characteristic of political connections is examined under one categorization only, which is according to the Regulation of Bank of Indonesia Number 12/3/PBI/2010 regarding Politically Exposed Person (PEP), thus we encourage future researcher to use better alternative measurement regarding this topic. 
JOURNAL OF SECURITY AND SUSTAINABILITY ISSUES ISSN 2029-7017/ISSN 2029-7025 (online)

2020 Volume 9 Number January

http://doi.org/10.9770/jssi.2020.9.J(13)

\section{References}

Adams, J. (2005). CEO Turnover and the Agency Cost of Debt. Texas Tech University. Retrieved April 5, 2019, from https://www.researchgate.net/publication/265076053

Bliss, M., Goodwin, J., Gul, F., \& Wong, A. (2018). The association between cost of debt and Hong Kong politically connected firms. Journal Of Contemporary Accounting \& Economics, 14(3), 321-334. https://doi.org/10.1016/j.jcae.2018.10.001

Bliss, M.A., \&Gul, F.A., (2012). Political connection and cost of debt: Some Malaysian Evidence. Journal of Banking and Finance 36, 1520-1527. https://doi.org/10.1016/j.jbankfin.2011.12.011

Bonaparte, Y. (2017). CEO Turnover and Political Repositioning. SSRN Electronic Journal. http://dx.doi.org/10.2139/ssrn.2991032

Chang, E., \& Wong, S. (2009). Governance with multiple objectives: Evidence from top executive turnover in China. Journal of Corporate Finance, 15(2), 230-244. https://doi.org/10.1016/j.jcorpfin.2008.10.003

Cheng, L., \& Leung, T. (2016). Government protection, political connection and management turnover in China. International Review of Economics \& Finance, 45, 160-176. https://doi.org/10.1016/j.iref.2016.03.010

Cooper, E. (2017). Corporate social responsibility, gender, and CEO Turnover. Managerial Finance, 43(5), 528-544. https://doi.org/10.1108/mf-02-2016-0049

Fan, H. (2017). Earnings Management, Politically Connected CEOs, and Politically Connected Independent Board Members: Evidence from China. International Journal Of Accounting And Financial Reporting, 7(1), 291. https://doi.org/10.5296/ijafr.v7i1.11277

Fan, H. \& Chen, L. (2017). Politically Connected Independent Directors and Effective Tax Rates in China. Asian Journal of Finance \& Accounting, 9(1), p.333. http://dx.doi.org/10.5296/ajfa.v9i1.11129

Fiordelisi, F., \& Ricci, O. (2014). Corporate culture and CEO turnover. Journal of Corporate Finance, 28, 66-82. https://doi.org/10.1016/j.jcorpfin.2013.11.009

Ghosh, A., \& Wang, J. (2018). Accounting Losses as a Heuristic for Managerial Failure: Evidence from CEO Turnovers. Journal of Financial and Quantitative Analysis, 54(2), 877-906. https://doi.org/10.1017/s0022109018000728

Harymawan, I., Agustia, D. and Kusuma Agung, A. (2017). Characteristics of politically connected firms in Indonesia. Problems and Perspectives in Management, 15(4), pp.17-23. http://dx.doi.org/10.21511/ppm.15(4).2017.02

Harymawan, I., Nasih, M., Madyan, M., \& Sucahyati, D. (2019). The Role of Political Connections on Family Firms' Performance: Evidence from Indonesia. International Journal of Financial Studies, 7(4), 55. https://doi.org/10.3390/ijfs7040055

Harymawan, I. \& Nowland, J. (2016). Political connections and earnings quality. International Journal of Accounting \& Information Management, 24(4), pp.339-356. https://doi.org/10.1108/IJAIM-05-2016-0056

Harymawan, I. (2018). Why do firms appoint former military personnel as directors? Evidence of loan interest rate in militarily connected firms in Indonesia. Asian Review of Accounting, 26(1), 2-18. https://doi.org/10.1108/ara-07-2016-0086

Kaplan, S., \& Minton, B. (2011). How Has CEO Turnover Changed?. International Review of Finance, 12(1), 57-87. https://doi.org/10.1111/j.1468-2443.2011.01135.x

Kong, D., Xiang, J., Zhang, J., \& Lu, Y. (2019). Politically connected independent directors and corporate fraud in China. Accounting \& Finance, 58(5), 1347-1383. https://doi.org/10.1111/acfi.12449

Mitnick, B. (1973). Fiduciary Rationality and Public Policy: The Theory of Agency and Some Consequences. SSRN Electronic Journal. Moy, R., \& Lee, C. (2000). Study guide for Statistics for business and financial economics [by] Cheng F. Lee, John C. Lee \& Alice C. Lee. Singapore: World Scientific Pub. Co.

Pfeffer, J. \& Salancik, G. R. (1978), The External Control of Organizations: A Resource Dependence Perspective, Harper \& Row, New York 
JOURNAL OF SECURITY AND SUSTAINABILITY ISSUES ISSN 2029-7017/ISSN 2029-7025 (online)

2020 Volume 9 Number January

http://doi.org/10.9770/jssi.2020.9.J(13)

Shi, H., Xu, H., \& Zhang, X. (2018). Do politically connected independent directors create or destroy value?. Journal of Business Research, 83, 82-96. https://doi.org/10.1016/j.jbusres.2017.10.009

Tsao, S., Lin, C. and Chen, V. (2015). Family ownership as a moderator between R\&D investments and CEO compensation. Journal of Business Research, 68(3), 599-606. https://doi.org/10.1016/j.jbusres.2014.09.001

Urban, D. (2019). The effects of culture on CEO power: Evidence from executive turnover. Journal of Banking \& Finance, $104,50-69$. https://doi.org/10.1016/j.jbankfin.2019.05.003

Volpin, P. (2002). Governance with poor investor protection: evidence from top executive turnover in Italy. Journal of Financial Economics, 64(1), pp.61-90. https://doi.org/10.1016/S0304-405X(02)00071-5

Wati, L.N., Primiana, H.I., Pirzada, K., Sudarsono, R. (2019). Political connection, blockholder ownership and performance, Entrepreneurship and Sustainability Issues, 7(1), 52-68. http://doi.org/10.9770/jesi.2019.7.1(5)

Weisbach, M. (1988). Outside directors and CEO turnover. Journal of Financial Economics, 20, 431-460. https://doi.org/10.1016/0304$\underline{405 x(88) 90053-0}$

You, J., \& Du, G. (2011). Are Political Connections a Blessing or a Curse? Evidence from CEO Turnover in China. Corporate Governance: An International Review, 20(2), 179-194. https://doi.org/10.1111/j.1467-8683.2011.00902

\section{Aknowledgements}

The authors would like to thank the auditor and anonymous reviewers for their supportive comments and suggestions. The authors received no direct partial funding from Tahir Research Grant 2018 for this research.

Ghassani AWANIS is a student at the Department of Accounting, Universitas Airlangga.

MOHAMMAD NASIH is a Professor and also a rector of Universitas Airlangga, Indonesia. His current research focuses include corporate governance issues, political and mili- tary connections in business, and financial reporting.

This work is licensed under the Creative Commons Attribution International License (CC BY). http://creativecommons.org/licenses/by/4.0/

(c) (i) Open Access 